\title{
PENGUASAAN BAHASA INGGERIS DALAM KALANGAN PELAJAR TAHUN SATU DI UKM
}

\author{
Maharam MAMAT \\ Pusat Citra Universiti, Universiti Kebangsaan Malaysia, 43600 \\ Bangi, Selangor, Malaysia \\ maharam@ukm.edu.my
}

Manuscript received 15 June 2016

Manuscript accepted 7 November 2016

\begin{abstract}
ABSTRAK
Kepentingan penguasaan Bahasa Inggeris tidak dapat dipertikaikan walaupun Bahasa Melayu menjadi bahasa kebangsaan di Malaysia. Bahasa global ini digunakan dengan meluas dan perlu dikuasai terutama golongan pelajar yang akan meneroka bidang ilmu dalam bidang pendidikan, seterusnya diaplikasi dalam dunia pekerjaan. Sekalipun Pengajaran Pembelajaran Matematik dan Sains (PPSMI) tidak lagi digunakan, proses menimba ilmu di universiti terutamanya memerlukan pelajar mempunyai penguasaan Bahasa Inggeris yang baik. Kajian ini mengenal pasti tahap penguasaan bahasa Inggeris dalam kalangan pelajar Tahun satu dari pelbagai fakulti di Universiti Kebangsaan Malaysia, seterusnya mengkaji adakah tahap penggunaan bahasa Inggeris seharian mempengaruhi penguasaan para pelajar terhadap bahasa tersebut. Kajian ini merumuskan bahawa penguasaan Bahasa Inggeris bagi pelajar Tahun satu di Universiti Kebangsaan Malaysia masih berada pada tahap sederhana dengan purata band MUET adalah band 2. Walaupun kebanyakan pelajar tidak dapat menguasai kemahiran berkomunikasi dari segi lisan dan bertulis dalam bahasa Inggeris, tetapi mereka tidak menghadapi masalah untuk membuat rujukan, mendapat arahan dan mengendalikan peralatan yang menggunakan arahan dalam bahasa Inggeris, menikmati hiburan seperti filem, permainan atas talian, menonton drama dan sebagainya. Mereka sering merujuk kamus dan bersikap positif untuk meningkatkan kemahiran berkenaan serta bersedia mengikuti kursus-kursus berkaitan sekiranya diberi peluang.
\end{abstract}

Kata kunci: penguasaan Bahasa Inggeris, band MUET, bahasa komunikasi, bahasa Inggeris 


\title{
THE COMMAND OF THE ENGLISH LANGUAGE AMONG FIRST-YEAR UNDERGRADUATE STUDENTS IN UKM
}

\begin{abstract}
The command of the English language is undoubtedly important in Malaysia, even though Malay language is the country's national language. English, as a global language, is used extensively and thus, need to be mastered, especially by students who are in the quest for knowledge and consequently, will be utilizing English in their working environment. Even though the Teaching and Learning of Mathematics and Science in English (PPSMI) policy is no longer in practiced, the learning process in universities requires undergraduate students to have a good proficiency in the English language. This study ains to identify the level of command in English among first year undergraduate students from various faculties in Universiti Kebangsaan Malaysia, and examines whether the students' daily usage of English have an effect on their overall command of it. This study shows that the level of command in English for first-year students in Universiti Kebangsaan Malaysia is still at the average level, with the MUET band 2. While a majority of students do not have the mastery of communicating verbally and writing in English, they do not seem to have difficulties to make references, receive orders, and use operating tools which have instructions in English, and enjoy entertainment such as films, online games and dramas. They would frequently turn to the dictionary and adopt positive attitudes in order to increase their expertise and grasp of English, and are also ready to enrol in courses if given the opportunity.
\end{abstract}

Keywords: command of English, MUET band, language of communication, English language, proficiency in English

\section{Pengenalan}

Bahasa Inggeris bukan sahaja bahasa ekonomi antarabangsa, malah menjadi bahasa teknologi bagi membolehkan negara menjadi lebih kompetitif dan berdaya saing terutama dalam era dunia tanpa sempadan yang membentuk persekitaran lebih liberal dalam penggunaan perkhidmatan dan sumber (Yahaya, Hashim, \& Che Shariff, 2008; Yahaya, Mohd Noor, Mokhtar, Mohd Rawian, Othman, \& Jusoff, 2009). Keperluan terhadap penguasaan bahasa Inggeris semakin mendesak dalam era globalisasi sehingga Perancis, China, Jepun dan negara-negara lain yang sebelum ini amat tertutup dengan bahasa ini mula mengambil langkah mempelajarinya. Dalam konteks dunia pendidikan pula, seseorang pelajar perlu menguasai bahasa Inggeris untuk memahami bahan-bahan bacaan dalam bahasa Inggeris yang lebih banyak dan mudah diperolehi. Bahasa Inggeris telah menjadi perantara dalam interaksi dalam kalangan penduduk dunia, termasuk mendapatkan pelbagai bahan bacaan, rujukan dan pengajaran pembelajaran ilmiah bermutu tinggi yang boleh didapati dengan meluas secara dalam talian. Rujukan ilmiah sebegini terdiri daripada 99\% diterbitkan dalam Bahasa Inggeris dan memerlukan penguasaan serta tahap 
pemahaman bahasa yang baik, selain kemampuan para pelajar itu menguasai teknik mencari maklumat itu sendiri. Situasi ini mendorong kerajaan melaksanakan dasar yang mahu pelajar menguasai Bahasa Inggeris. Kajian awal dilakukan Kementerian Pengajian Tinggi di semua Institusi Pengajian Tinggi Awam mendapati bahawa tahap penguasaan Bahasa Inggeris dalam kalangan pelajar kurang memuaskan dengan $29.2 \%$ daripada 120,000 responden berada pada band 1 dan band 2 . Tahap ini merupakan tahap terendah dalam standard yang ditetapkan oleh Malaysian Universiti English Test (MUET) (Bernama, 22 Januari 2007).

Kesedaran tentang pentingnya penguasaan Bahasa Inggeris dalam kalangan pelajar Malaysia telah lama disedari, mendorong Kementerian Pendidikan melaksanakan Pengajaran Pembelajaran Sains dan Matematik dalam Bahasa Inggeris (PPSMI) secara berperingkat bagi pelajar Tahun 1, Tingkatan 1 dan Tingkatan 6 Bawah. Soalan peperiksaan menggunakan dwibahasa telah diperkenalkan, manakala penggunaan Bahasa Inggeris sepenuhnya di dalam peperiksaan Sains dan Matematik bermula pada tahun 2008 bagi peperiksaan Ujian Penilaian Sekolah Rendah (UPSR) dan 2007 bagi Sijil Pelajaran Malaysia (SPM). Pada tahun 2006, pelajar tingkatan 4 aliran teknikal di Sekolah Menengah Teknik pula telah menggunakan Bahasa Inggeris dalam pembelajaran mereka melibatkan kursus Pengajian Kejuruteraan awam, Elektrik dan Jentera serta Lukisan Kejuruteraan. Namun begitu, pada 2009, PPSMI telah dibubarkan dan diperkenalkan dasar "Memartabatkan Bahasa Malaysia dan memperkukuhkan Bahasa Inggeris".

Menurut Ismail (2012), para majikan menjangkakan graduan dalam pasaran pekerjaan mempunyai kemahiran insaniah (soft skills) seperti kemahiran komunikasi, penguasaan bahasa Inggeris, pengetahuan am dan semasa, kebolehan untuk melayan pelanggan, dan sebagainya. Penguasaan Bahasa Inggeris yang lemah merupakan antara lima faktor utama yang mempengaruhi kesukaran graduan mendapatkan pekerjaan. Ini disokong dengan kajian dilakukan Abdullah (2007) yang mendapati $33.3 \%$ pengangguran dalam kalangan graduan berpunca daripada penguasaan Bahasa Inggeris yang lemah. Menurut Kementerian Sumber Manusia terdapat seramai 20,217 orang siswazah yang menganggur di negara ini, merangkumi siswazah lulusan dalam dan luar negara (The Star, 2006a), antaranya berpunca daripada penguasaan bahasa Inggeris yang lemah dan tidak memahami keperluan majikan serta pekerjaan yang ditawarkan. Ini menyebabkan mereka tidak layak diterima berkerja walaupun terdapat banyak kekosongan sehingga Kementerian Sumber Manusia melaksanakan Program Latihan Siswazah Menganggur bagi membantu menangani isu pengangguran dalam kalangan siswazah (Berita Harian, 2005; The Sun Daily, 2006). Program ini merupakan langkah jangka pendek bagi mengatasi masalah pengangguran dalam kalangan siswazah dengan menawarkan kursus-kursus bahasa Inggeris, pembangunan siswazah dan persijilan professional dalam Linux, Microsoft dan aplikasi Cisco melibatkan perbelanjaan melebihi RM150 juta (sehingga 2004) (Maniam \& Liong, 2007; The Star, 2006b).

Penguasaan pelajar di dalam Bahasa Inggeris memberikan mereka kelebihan untuk menerokai pelbagai ilmu, melakukan rujukan dan membuat penyelidikan, seterusnya diaplikasikan apabila memasuki dunia pekerjaan. Pelajar yang menguasai sekurang-kurangnya dua bahasa mempunyai banyak kelebihan berbanding pelajar yang menguasai satu bahasa sahaja. Mereka mampu menguasai bahan rujukan, 
mendapat lebih banyak info terkini dengan cepat, berkeyakinan mengemukakan hujah dan berdebat, seterusnya mampu berkomunikasi dengan yakin dan selesa dari segi penggunaan perbendaharaan kata, ejaan dan tatabahasa yang betul (Bochner, 1996). Ini secara langsung memperkukuhkan kemahiran membaca, mendengar, menulis dan bertutur yang menjadi kemahiran asas perlu dikuasai pelajar (Selamat, 2000).

\section{Tujuan Kajian}

Kajian ini mengenal pasti tahap penguasaan bahasa Inggeris dalam kalangan pelajar tahun satu di Universiti Kebangsaan Malaysia, seterusnya meneliti bagaimana tahap penggunaan bahasa Inggeris seharian mempengaruhi penguasaan terhadap bahasa tersebut.

\section{Persoalan Kajian}

Kajian ini dijalankan untuk mengkaji tahap penguasaan bahasa Inggeris dalam kalangan pelajar Tahun satu di Universiti Kebangsaan Malaysia, sama ada para pelajar tersebut menguasai sepenuhnya bahasa kedua ini. Kajian ini juga turut meneliti sama ada tahap penggunaan bahasa Inggeris mempengaruhi penguasaan pelajar terhadap bahasa tersebut. Kajian ini dilakukan terhadap kumpulan pelajar tahun satu Universiti Kebangsaan Malaysia, Bangi yang terdiri daripada pelbagai fakulti. Responden dipilih secara rawak. Kajian berkaitan penggunaan dan penguasaan Bahasa Inggeris ditekankan kepada aspek kemahiran membaca, bertutur, menulis dan mendengar melibatkan 90 responden yang terdiri daripada 67 orang pelajar perempuan dan 23 orang pelajar lelaki.

\section{Kaedah Kajian}

Selain melakukan resensi kepustakaan, kajian ini menggunakan borang soalselidik sebagai kaedah mendapatkan instrumen kajian. Menurut Konting (2000), soal selidik lebih praktikal dan berkesan digunakan kerana penggunaannya dapat meningkatkan ketepatan dan kebenaran gerak balas yang diberikan oleh sampel, serta tidak dipengaruhi oleh gerak laku penyelidik. Responden bebas menyatakan pendapat sendiri semasa menjawab setiap item yang diberikan. Salah satu kebaikan soal selidik adalah ianya menjamin kerahsiaan dan ini akan dapat mencungkil maklumat yang tepat dari responden (Ary, Jacob, \& Razarieh, 1990).

Borang soalselidik diedarkan kepada pelajar tahun satu secara rawak di beberapa buah kolej kediaman. Segala maklumat yang diterima ditafsirkan secara kuantitatif. Borang soal selidik mengandungi soalan yang dibahagi kepada dua bahagian iaitu Bahagian A dan Bahagian B. Bahagian A lebih menjurus kepada soalan berkaitan demografi termasuk keputusan Band MUET. MUET merupakan singkatan kepada Malaysian University English Test. Ujian ini wajib diambil oleh semua mahasiswa yang melanjutkan pelajaran ke universiti bagi menguji tahap pengguasaan Bahasa Inggeris pelajar. Bahagian B pula mengandungi soalan berkaitan tahap penguasaan Bahasa Inggeris dan faktor-faktor yang menjurus 
kepada kemahiran tersebut. Bahagian ini terbahagi kepada dua aspek, iaitu, pertama: penggunaan bahasa Inggeris dalam pembelajaran meliputi kemahiran lisan, bertulis dan mendengar, dan kedua: kekerapan penggunaan bahasa Inggeris dalam kehidupan seharian.

\section{Kajian Lepas}

Penguasaan bahasa Menurut Persatuan TESOL yang dipetik Kamarudin, Sidek, Abdul Majid, Ibrahim, Mohamad Sharif, dan Mohamed (2008) ditakrifkan sebagai tahap penguasaan seseorang individu menggunakan bahasa dalam komunikasi lisan dan bertulis. Abdul Latif dan Abu Hanifah (2010) mengkaji tahap penguasaan dan penggunaan Bahasa Inggeris dalam kalangan pelajar PKPG di Fakulti Pendidikan Universiti Teknologi Malaysia mendapati bahawa penguasaan Bahasa Inggeris dikalangan pelajar tahun 4 program Sarjana Muda Teknologi serta Pendidikan (Kemahiran Hidup) berada pada tahap sederhana. Kebanyakan pelajar masih tidak dapat memahami pengajaran, tidak dapat menguasai kemahiran berkomunikasi secara lisan dan bertulis, tidak menguasai pengetahuan dalam mata pelajaran yang diajar dalam bahasa Inggeris dan kurang penguasaan bahasa tersebut di dalam kelas. Kajian ini juga mendapati bahawa tahap penguasaan bahasa Inggeris yang rendah itu berlaku kerana penggunaan bahasa Inggeris dalam kalangan pelajar itu sendiri berada pada tahap yang rendah. Sebilangan besar responden kajian didapati hampir tidak pernah menggunakan bahasa Inggeris dalam kehidupan seharian mereka dari sama ada untuk komunikasi secara lisan atau ketika membuat rujukan. Dapatan ini sama seperti diperolehi dalam kajian Maniam dan Liong (2007) iaitu pencapaian pelajar dalam peperiksaan semakin morosot terutama di sekolah menengah harian bandar dan sekolah menengah harian luar bandar. Malah kajian dilakukan Haron, Gapor, Masran, Ibrahim, dan Mohamed Nor (2008) juga mendapati bahawa dasar menggunakan Bahasa Inggeris untuk mengajar Matematik dan Sains telah gagal untuk meningkatkan pembelajaran dan prestasi Matematik dan Sains pelajar, terutama pelajar Melayu/Bumiputera.

Abdul Halim, Hidzir, Woon, dan Marriappen (2011) dalam kajiannya mengenal pasti persepsi, penerimaan, dan kecenderungan pelajar mengaplikasikan penggunaan Bahasa Inggeris sebagai bahasa pengantar dalam Peperiksaan Akhir sesi Disember 2010 dalam kalangan pelajar diploma Akauntan mendapati bahawa kebanyakan pelajar kurang bersetuju Bahasa Inggeris digunakan dalam peperiksaan akhir dan menjadi bahasa pengantar dalam peperiksaan termasuk golongan pelajar yang mempunyai CGPA 3.5 ke atas. Dapatan Kajian ini memberi gambaran bahawa berlaku krisis keyakinan pelajar untuk menjawab soalan peperiksaan dalam Bahasa Inggeris, iaitu selari dengan ketidakbolehan mereka untuk menulis dalam Bahasa Inggeris mengikut tatabahasa yang betul. Hal yang sama diperolehi dalam kajian Abu Bakar dan Abang Madni (2010), iaitu faktor sikap, rakan sebaya, dan ibu bapa mempengaruhi penguasaan bahasa Inggeris pelajar-pelajar tetapi faktor ini berlaku pada tahap yang sederhana.

Pada umumnya, Bahasa Inggeris kurang digunakan dalam aktiviti seharian pelajar. Mereka beranggapan bahawa bahasa Inggeris hanya menjadi syarat untuk lulus dalam mata pelajaran yang diambil. Ini menyebabkan kemampuan menguasai 
bahasa antarabangsa ini dengan baik sangat terhad. Mereka juga didapati kurang berkomunikasi menggunakan bahasa Inggeris bersama rakan sebaya semasa membuat tugasan berkumpulan dan dalam kehidupan seharian yang turut menyumbang kepada penguasaan bahasa Inggeris yang sederhana (Zainudin \& Dayang Rozina, 2010). Menurut Carhill (2008), tahap penguasaan bahasa Inggeris individu dipengaruhi oleh kekerapan penggunaan dalam kehidupan seharian berbanding menggunakan bahasa tersebut hanya semasa proses pembelajaran sahaja. Dapatan kajian ini juga sejajar dengan pendapat Klein (1986), Abdul Halim et al. (2011) dan Abu Bakar dan Abang Madni (2010). Abdul Halim et al. (2011) mencadangkan agar penggunaan istilah-istilah teknikal di dalam Bahasa Inggeris ditingkatkan dalam bidang selain mengadakan program 'Mentoring' antara pelajar yang bagus dan pelajar yang lemah sebagai salah satu usaha untuk meningkatkan penguasaan Bahasa Inggeris di dalam kalangan pelajar.

Ketidakupayaan pelajar menguasai bahasa Inggeris menimbulkan kesan jangka panjang yang perlu ditangani dengan bijak. Menggunakan Bahasa Inggeris sebagai bahasa perantaraan dalam pengajaran dan pembelajaran tidak menyelesaikan masalah ini untuk jangka masa pendek kerana turut melibatkan kemerosotan pencapaian pelajar dalam subjek yang lain pula. Kajian dilakukan Mohamed (2008) mendapati bahawa kebanyakan pelajar UTM mempunyai band MUET (Malaysian University English Test) yang lemah (Band 3 dan ke bawah) menyebabkan wujud pelbagai dilema dan masalah apabila pengajaran dan pembelajaran menggunakan bahasa Inggeris. Banyak kajian dilakukan tentang tahap penguasaan bahasa Inggeris yang lemah dalam kalangan pelajar, contohnya pengajaran dan pembelajaran Sains dan Matematik dalam Bahasa Inggeris (PPSMI) lebih memberi impak yang berganda terhadap pencapaian pelajar yang sederhana dan lemah dalam akademik berbanding pelajar cemerlang (Abedi, Lord, \& Plummer, 1995; Cocking \& Chipman, 1998; Madison, 1990). Kajian Ishak dan Mohamed (2010) turut mengesan pelaksanaan polisi ini terhadap pelajar beberapa buah fakulti di UTM Skudai yang diambil secara rawak. Kajian ini mendapati bahawa tahap kesediaan, minat dan keyakinan pelajar UITM terhadap PPSMI berada pada aras yang sederhana dan kurang memuaskan. Walau bagaimanapun, majoriti pelajar didapati positif dan bersetuju dengan perlaksanaan polisi terbabit dan menyatakan bahawa ia penting bagi penguasaan bahasa Inggeris, kerjaya dan masa hadapan mereka.

Pelajar universiti menyedari tentang kepentingan penguasaan Bahasa Inggeris pada zaman ini. Mereka juga tahu bahawa penguasaan bahasa antarabangsa itu menjadi salah satu komponen penting yang dinilai semasa memohon pekerjaan, malah, banyak kes pengangguran berlaku kerana kegagalan calon untuk berkomunikasi dengan baik dalam Bahasa Inggeris. Kajian Abdullah (2007) mendapati 33.3\% pengangguran di kalangan graduan adalah disebabkan kelemahan dalam penguasaan Bahasa Inggeris. Tiga buah Kementerian dan Jabatan kerajaan (Kementerian Pengajian Tinggi, Kementerian Sumber Manusia dan Majlis Tindakan Ekonomi Negara) telah membuka pendaftaran secara dalam talian (online) kepada graduan bagi mengesan kadar pengangguran pada awal tahun 2006 dan didapati terdapat $24,608(41.5 \%)$ graduan yang benar-benar menganggur dan $36,642(58.5 \%)$ graduan lagi telah bekerja sementara atau menjawat jawatan yang 
tidak setaraf dengan kelulusan sebenar mereka. Tiga faktor utama dikenalpasti menjejaskan peluang pekerjaan mereka meliputi faktor kurang pengalaman bekerja (49.7\%), penguasaan Bahasa Inggeris yang lemah (33.3\%) dan bidang pengajian yang tidak sesuai (32.3\%). Kajian pengangguran daripada perspektif majikan dilakukan Ismail (2012) pula mendapati bahawa antara faktor graduan tidak diambil bekerja atau menganggur disebabkan pencapaian akademik yang rendah, sikap dan semangat keyakinan diri yang rendah, tidak bermotivasi dan tiada halatuju, kurang bakat kepemimpinan, kurang persediaan menghadiri temu duga, jangkaan gaji yang tidak realistik, latar belakang pendidikan yang tidak sesuai dengan bidang pekerjaan dan kurang aktiviti ko-kurikulum.

\section{Dapatan dan Perbincangan}

Era globalisasi menyaksikan hampir 99\% maklumat menggunakan Bahasa Inggeris dan ini menjadikan bahasa tersebut sebagai bahasa dunia yang penting. Dunia mula bersifat global dan antarabangsa melalui perubahan struktur kerjaya, pendidikan, latihan kemahiran dan mencabar corak hidup yang selama ini bersifat jumud. Penguasaan Bahasa Inggeris menjadi indikator terhadap keupayaan graduan yang cekap berbahasa, berkomunikasi dan berhujah, kekuatan daya fikir dan menyelesaikan masalah, kecerdasan emosi dan sifat kepimpinan. Ini juga menjadi asas terhadap Pengajaran Pembelajaran Sains dan Matematik dalam Bahasa Inggeris (PPSMI) yang diperkenalkan di sekolah, seterusnya universiti pada 2007, walaupun kemudiannya dimansuhkan secara berperingkat pada 2012.

Menggunakan Bahasa Inggeris dalam pengajaran dan pembelajaran terutama untuk subjek Matematik, Sains dan kursus-kursus bersifat teknikal tidak dapat menyelesaikan masalah penguasaan bahasa tersebut, sebaliknya telah mengurangkan minat pelajar terhadap Sains dan Matematik pula. Pencapaian pelajar yang sederhana dan lemah dalam Bahasa Inggeris turut merosot bagi mata pelajaran Sains dan Matematik. Menurut Nambiar, Noraini, dan Krish (2008), penguasaan bahasa seseorang pelajar bergantung kepada aspek mendengar, membaca, menulis dan bertutur yang menjadi kemahiran asas pembelajaran. Dalam proses pembelajaran di universiti, pelajar didedahkan dengan kemahiran mendengar melalui kuliah, kemahiran menulis, membaca dan komunikasi turut diperolehi apabila melakukan gerak kerja berkumpulan, berinteraksi dan menyiapkan tugasan yang sentiasa diasah semasa belajar (Selamat, 2000). Kelemahan utama pelajar Melayu adalah penguasaan Bahasa Inggeris untuk berkomunikasi (Yahaya et al., 2008). Dapatan ini sejajar dengan kajian dilakukan Taib (1998) tentang penggunaan Bahasa Inggeris di Malaysia pada ketika itu yang hanya tertumpu kepada golongan atasan sahaja. Walaupun begitu, kumpulan pelajar yang memperoleh pencapaian MUET yang tinggi mempunyai tahap minat yang tinggi juga. Kajian dilakukan Mohamed dan Mokhter (2010) pula mendapati bahawa semakin baik pencapaian MUET seseorang pelajar, maka semakin tinggi kesediaan, minat dan keyakinan pelajar berkenaan. Ini bermakna, pencapaian MUET amat mempengaruhi tahap minat pelajar untuk berkomunikasi dalam Bahasa Inggeris.

Walaupun UKM ditubuhkan dengan hasrat untuk mewujudkan sebuah institusi pengajian tinggi yang memartabatkan bahasa Melayu sebagai bahasa 
pengantar dalam semua bidang pangajian dan keilmuan, namun pada masa yang sama Bahasa Inggeris tidak dipinggirkan dengan kesedaran untuk memantapkannya. Bahasa Inggeris digunakan secara meluas di UKM bagi kursus bahasa Inggeris sebagai bahasa kedua dan kursus undang-undang, manakala kursus-kursus lain yang bersifat merentas kurikulum hanya menggunakan $5 \%$ sahaja. Walau bagaimanapun, semua pelajar masih diwajibkan mengikuti kelas bahasa Inggeris untuk beberapa jam kredit yang tertentu mengikut tahap penguasaan Bahasa Inggeris pelajar. Justeru itu, kajian ini dilakukan dalam kalangan pelajar tahun satu sesi 2013/2014 di UKM, melibatkan seramai 90 orang responden, iaitu $75 \%$ terdiri daripada responden lelaki dan $25 \%$ responden wanita. Responden terdiri daripada $39 \%$ pelajar Fakulti Sains Sosial dan Kemanusiaan (FSSK), 36\% pelajar Fakulti Pengajian Islam (FPI), 14\% daripada Fakulti Sains dan Teknologi (FST), 2\% daripada Fakulti Ekonomi dan Pengurusan (FEP), 5\% daripada Fakuti Pendidikan (FPEND), 2\% pelajar daripada Fakulti Kejututeraan dan Alam Bina (FKAB), dan hanya 1\% adalah pelajar daripada Fakulti Undang-Undang (FUU) dan Fakulti Teknologi Sains Maklumat. Menerusi kajian ini, berikut adalah pencapaian keputusan MUET yang diperolehi responden yang terlibat iaitu:

Jadual 1

Keputusan MUET responden

\begin{tabular}{ccc}
\hline Band & $\mathrm{F}$ & $\%$ \\
\hline 1 & 2 & 2.2 \\
2 & 56 & 62.2 \\
3 & 24 & 26.7 \\
4 & 8 & 8.9 \\
5 & 0 & 0.00 \\
6 & 0 & 0.00 \\
\hline Jumlah & 90 & 100 \\
\hline
\end{tabular}

Berdasarkan Jadual 1, didapati bahawa sebanyak $62.2 \%$ responden mencapai keputusan Band 2 dan hanya 8.9\% sahaja yang memperoleh Band 4 . MUET band 2 dinilai sebagai, "penggunaan bahasa Inggeris adalah terhad" (Majlis Peperiksaan Malaysia, 2006). Kebolehan komunikasi pelajar pada tahap ini pula tidak fasih, kerap berlaku penggunaan bahasa yang tidak sesuai dan terdapat kesalahan tatabahasa. Dari segi pemahaman, pencapaian pelajar pada tahap ini terhad dari segi bahasa dan konteks, serta terhad pelaksanaan tugasan yang melibatkan penggunaan bahasa tersebut. Bersandarkan keputusan peperiksaan MUET dalam Jadual 1, disimpulkan bahawa penguasaan bahasa Inggeris dalam kalangan pelajar tahun satu di UKM yang menjadi responden kajian ini masih belum memuaskan, dan ini menyebabkan mereka mengalami kesulitan untuk menguasai ilmu dalam pembelajaran mereka. Dapatan ini tidak mengejutkan kerana sebahagian besar responden untuk kajian ini terdiri daripada 39\% pelajar Fakulti Sains Sosial dan Kemanusiaan (FSSK), dan 36\% pelajar Fakulti Pengajian Islam (FPI) yang banyak menggunakan Bahasa Melayu dan Bahasa Arab dalam proses pembelajaran mereka. 


\section{Tahap Penguasaan Bahasa Inggeris Pelajar Tahun 1 UKM}

Analisis pada bahagian ini menjawab persoalan kajian yang pertama, iaitu untuk mengetahui tahap penguasaan bahasa Inggeris dalam kalangan pelajar tahun satu di Universiti Kebangsaan Malaysia. Jadual 2 menunjukkan jawapan kepada soalan 3, 4, $5,6,7,8$ dan 9 merangkumi aspek penggunaan bahasa Inggeris ketika sesi pembelajaran.

Jadual 2

Tahap penguasaan Bahasa Inggeris pelajar tahun satu di UKM

\begin{tabular}{|c|c|c|c|c|c|c|c|c|c|c|c|}
\hline \multirow{2}{*}{$\begin{array}{l}\text { No. } \\
\text { soalan }\end{array}$} & \multirow[t]{2}{*}{ Soalan } & \multicolumn{2}{|c|}{ STS } & \multicolumn{2}{|c|}{ TS } & \multicolumn{2}{|c|}{ TP } & \multicolumn{2}{|c|}{$S$} & \multicolumn{2}{|c|}{ SS } \\
\hline & & $\mathrm{F}$ & $\%$ & $\mathrm{~F}$ & $\%$ & $\mathrm{~F}$ & $\%$ & $\mathrm{~F}$ & $\%$ & $\mathrm{~F}$ & $\%$ \\
\hline 3. & $\begin{array}{l}\text { Saya lebih selesa dengan penggunaan } \\
\text { Bahasa Inggeris bagi subjek Sains / } \\
\text { Matematik. }\end{array}$ & 2 & 2.2 & 6 & 7 & 12 & 13 & 43 & 48 & 27 & 30 \\
\hline 4. & $\begin{array}{l}\text { Saya tidak berasa takut untuk bertanya } \\
\text { di dalam Bahasa Inggeris kepada } \\
\text { pensyarah semasa di dalam kelas. }\end{array}$ & 1 & 1.1 & 10 & 11 & 41 & 46 & 33 & 37 & 5 & 6 \\
\hline 5. & $\begin{array}{l}\text { Saya boleh berbincang menggunakan } \\
\text { Bahasa Inggeris dalam kumpulan. }\end{array}$ & 0 & 0.0 & 11 & 12 & 39 & 43 & 35 & 39 & 5 & 6 \\
\hline 6. & $\begin{array}{l}\text { Saya mudah memahami arahan yang } \\
\text { disampaikan dalam Bahasa Inggeris. }\end{array}$ & 0 & 0.0 & 4 & 4 & 22 & 24 & 55 & 61 & 9 & 10 \\
\hline 7. & $\begin{array}{l}\text { Pensyarah perlu memiliki suara yang } \\
\text { lantang dan jelas sekiranya Bahasa } \\
\text { Inggeris digunakan sebagai medium } \\
\text { pengajaran. }\end{array}$ & 0 & 0.0 & 4 & 4 & 6 & 7 & 50 & 57 & 30 & 33 \\
\hline 8. & $\begin{array}{l}\text { Saya boleh menulis dalam Bahasa } \\
\text { Inggeris tanpa melakukan kesalahan } \\
\text { tatabahasa yang banyak. }\end{array}$ & 3 & 3.3 & 21 & 23 & 45 & 50 & 17 & 19 & 4 & 4 \\
\hline 9. & $\begin{array}{l}\text { Saya tiada masalah dengan bahan } \\
\text { rujukan yang ditulis dalam Bahasa } \\
\text { Inggeris. }\end{array}$ & 0 & 0.0 & 7 & 8 & 34 & 38 & 42 & 41 & 7 & 8 \\
\hline
\end{tabular}

Analisis jawapan yang diperolehi daripada responden menggambarkan tentang penguasaan Bahasa Inggeris mereka berada pada tahap sederhana. Hampir separuh daripada responden (46\%) 'tidak pasti' dan berasa ragu-ragu untuk bertanya kepada pensyarah menggunakan bahasa Inggeris. Ini menggambarkan bahawa keyakinan responden berada pada tahap yang lemah kerana penguasaan mereka yang masih belum mencukupi dalam penggunaan bahasa ini. Dapatan ini sejajar dengan kajian Klein (1986) yang menyatakan bahawa pembelajaran bahasa memerlukan latihan komunikasi setiap hari. Apabila pelajar malu untuk bertutur menggunakan Bahasa Inggeris dalam kehidupan seharian mereka, tahap penguasaan bahasa tersebut turut menjadi lemah kerana sifat itu menjadi punca utama lemahnya penguasaan sesuatu bahasa. Sebaliknya, Pelajar yang mempunyai penguasaan Bahasa Inggeris yang baik kerap menggunakan bahasa Inggeris dalam komunikasi seharian (Kamsur, 2015). Semakin kerap penggunaan Bahasa Inggeris dalam kehidupan seharian, maka semakin mahir dan tinggi tingkat penguasaan bahasa tersebut.

Walaupun $61 \%$ daripada responden memahami arahan yang diberikan dalam Bahasa Inggeris, namun mereka tidak dapat berbincang menggunakan bahasa Inggeris kerana penguasaan bahasa Inggeris mereka yang rendah. Malah, seramai $43 \%$ responden "tidak pasti" sama ada mereka boleh berbincang menggunakan 
bahasa Inggeris dalam kumpulan perbincangan atau tidak. Bagi soalan berkaitan penggunaan bahan rujukan berbahasa Inggeris (soalan 9), 41\% responden mengakui tidak mengalami masalah untuk memahaminya, manakala sebanyak $38 \%$ memilih "tidak pasti". Ini menggambarkan bahawa, sebahagian besar responden berkeyakinan dan memahami arahan serta rujukan berbahasa Inggeris. Walau bagaimanapun, masih terdapat $8 \%$ responden sahaja yang "bersetuju" bahawa mereka bermasalah untuk memahami bahan rujukan yang ditulis dalam bahasa Inggeris.

Bagi soalan 8 berkaitan kebolehan menulis dalam Bahasa Inggeris tanpa melakukan kesalahan tatabahasa yang banyak, pilihan jawapan bagi kategori "tidak pasti" merupakan pilihan tertinggi iaitu sebanyak 50\%. Walaupun responden memahami arahan dan bahan rujukan berbahasa Inggeris, namun mereka tidak mempunyai keyakinan untuk menulis dalam bahasa Inggeris tanpa melakukan kesalahan tatabahasa, ayat atau frasa dalam bahasa Inggeris. Mereka kerap melakukan kesalahan secara tidak seragam disebabkan kurangnya pengetahuan tentang ilmu tatabahasa dan jarang mempraktikkannya dalam penulisan. Hasil ini bertepatan dengan penilaian band MUET bagi band 2 yang bersifat "terhad dari segi penggunaan, penguasaan dan kebolehan komunikasi, selain kerap berlaku kesalahan tatabahasa dan penggunaan kata yang tidak sesuai", sedangkan kumpulan ini merupakan majoriti responden kajian iaitu meliputi $62.2 \%$.

Menurut Abdul Latif dan Abu Hanifah (2010), jika pelajar ingin mendapatkan ilmu pengetahuan yang lebih luas dalam sesuatu bidang yang dipelajari, mereka perlu menguasai bahasa Inggeris. Kurangnya pendedahan atau kurang ilmu pengetahuan terhadap bahasa Inggeris dari segi kosa kata dan istilah menyebabkan responden mengalami kesukaran untuk membuat rujukan tersebut. Berdasarkan 48\% jawapan "setuju" dan 30\% lagi "Sangat Setuju" untuk soalan 3 menyatakan bahawa mereka selesa untuk menggunakan bahasa Inggeris bagi subjek Sains dan Matematik. Ini menunjukkan bahawa responden yang berada dalam bidang Sains dan Matematik tidak bermasalah dengan penggunaan bahasa Inggeris dalam pengajaran dan pembelajaran kursus tersebut. Mereka ternyata sudah biasa dan memahami dengan terminologi serta istilah bahasa Inggeris dalam bidang ini kerana telah terdedah dengan Pengajaran Pembelajaran Sains dan Matematik dalam bahasa Inggeris (PPSMI) semasa di sekolah rendah.

Rumusannya, dapat dikatakan bahawa penguasaan bahasa Inggeris dalam kalangan pelajar tahun satu di UKM masih berada pada tahap sederhana. Penggunaan Bahasa Inggeris sebagai alat komunikasi masih terhad dalam sesi perbincangan kumpulan kecil dan di dalam dewan kuliah kerana kurang yakin untuk digunakan walaupun bertanya kepada pensyarah. Responden memerlukan persekitaran yang sesuai untuk mendorong penggunaan Bahasa Inggeris dalam komunikasi seperti kelantangan dan kejelasan suara pensyarah apabila bertutur dalam Bahasa Inggeris. Ini menggambarkan bahawa pengaruh seseorang pensyarah dan cara penggunaan bahasa Inggeris dalam pengajaran pembelajaran mempengaruhi kefahaman pelajar terhadap arahan yang diberikan. Hasil kajian ini juga menunjukkan bahawa pelajar tidak mempunyai masalah dari sudut pemahaman terhadap arahan, pembacaan, dan membuat rujukan dalam bahasa Inggeris. 


\section{Tahap Penguasaan Bahasa Inggeris Seharian Pelajar}

Bahagian ini menganalisis tahap penggunaan bahasa Inggeris seharian yang mempengaruhi penguasaan para pelajar terhadap bahasa tersebut dan bagaimana faktor persekitaran mempengaruhi penggunaan bahasa ini. Soalan 1, 2, 10, 11, 12, 13, 14, 15 merangkumi aspek kekerapan penggunaan bahasa Inggeris dalam kehidupan seharian responden seperti dipaparkan dalam Jadual 3 berikut:

Jadual 3

Penggunaan bahasa Inggeris seharian dan pengaruh persekitaran

\begin{tabular}{|c|c|c|c|c|c|c|c|c|c|c|c|}
\hline \multirow{2}{*}{$\begin{array}{l}\text { No. } \\
\text { Soalan }\end{array}$} & \multirow[t]{2}{*}{ Soalan } & \multicolumn{2}{|c|}{ STS } & \multicolumn{2}{|c|}{ TS } & \multicolumn{2}{|c|}{ TP } & \multicolumn{2}{|c|}{$\mathrm{S}$} & \multicolumn{2}{|c|}{ SS } \\
\hline & & $\mathrm{F}$ & $\%$ & $\mathrm{~F}$ & $\%$ & $\mathrm{~F}$ & $\%$ & $\mathrm{~F}$ & $\%$ & $\mathrm{~F}$ & $\%$ \\
\hline 1. & $\begin{array}{l}\text { Saya kerap menggunakan kamus untuk } \\
\text { merujuk perkataan dalam Bahasa Inggeris } \\
\text { yang saya tidak tahu maksudnya. }\end{array}$ & 1 & 1.1 & 9 & 10 & 12 & 12 & 42 & 47 & 26 & 29 \\
\hline 2. & $\begin{array}{l}\text { Saya memiliki banyak bahan bacaan } \\
\text { Bahasa Inggeris. }\end{array}$ & 4 & 4.4 & 23 & 26 & 38 & 42 & 17 & 19 & 8 & 9 \\
\hline 10. & $\begin{array}{l}\text { Saya menggunakan Bahasa Inggeris dalam } \\
\text { pergaulan seharian. }\end{array}$ & 9 & 10 & 38 & 42 & 33 & 37 & 10 & 11 & 0 & 0 \\
\hline 11. & $\begin{array}{l}\text { Kritikan daripada orang sekeliling } \\
\text { mempengaruhi tahap penggunaan Bahasa } \\
\text { Inggeris saya. }\end{array}$ & 0 & 0.0 & 14 & 16 & 33 & 37 & 36 & 40 & 7 & 8 \\
\hline 12. & $\begin{array}{l}\text { Saya yakin untuk menggunakan Bahasa } \\
\text { Inggeris di hadapan khalayak ramai. }\end{array}$ & 3 & 3.0 & 18 & 20 & 48 & 53 & 19 & 21 & 2 & 2 \\
\hline 13. & $\begin{array}{l}\text { Saya tiada masalah mengendali / } \\
\text { mengguna sistem yang menggunakan } \\
\text { Bahasa Inggeris (seperti komputer ) }\end{array}$ & 0 & 0.0 & 4 & 4 & 9 & 10 & 52 & 58 & 25 & 28 \\
\hline 14. & $\begin{array}{l}\text { Saya tiada masalah untuk memahami } \\
\text { bentuk -bentuk hiburan seperti lagu, filem } \\
\text { atau animasi dalam Bahasa Inggeris. }\end{array}$ & 0 & 0.0 & 5 & 6 & 12 & 13 & 56 & 62 & 17 & 19 \\
\hline 15. & $\begin{array}{l}\text { Jika diberi peluang, saya ingin mengikuti } \\
\text { kursus-kursus yang boleh menambah baik } \\
\text { kemahiran berbahasa Inggeris saya. }\end{array}$ & 0 & 0.0 & 2 & 2 & 5 & 6 & 47 & 52 & 36 & 40 \\
\hline
\end{tabular}

Merujuk kepada Jadual 3, dapat disimpulkan bahawa responden jarang menggunakan bahasa Inggeris dalam kehidupan seharian mereka (soalan 10), dengan jumlah peratusan jawapan bagi "tidak setuju" merupakan jumlah tertinggi (42\%) berbanding "setuju" (11\%) sahaja. Jika dilihat dari sudut keyakinan responden untuk bertutur dalam bahasa Inggeris di khalayak ramai pula, hanya $21 \%$ "bersetuju" dan yakin, berbanding 53\% responden menjawab "tidak pasti". Jumlah $3 \%$ responden yang "sangat tidak bersetuju" dan $20 \%$ responden yang "tidak bersetuju" untuk menggunakan bahasa Inggeris di khalayak ramai merupakan satu jumlah yang kecil, sama situasinya dengan responden yang yakin untuk menggunakan bahasa Inggeris di khalayak ramai (23\%). Ini bermakna, tahap keyakinan yang rendah dalam penggunaan bahasa Inggeris mempengaruhi tahap penggunaan bahasa tersebut jika dilihat kepada sejumlah $53 \%$ responden yang "tidak pasti".

Apabila dikaitkan hal ini dengan soalan 11, didapati bahawa $40 \%$ responden merasa terpengaruh dengan kritikan daripada orang sekeliling. Ini bermakna, responden mampu meningkatkan penguasaan berbahasa Inggeris apabila mendapat sokongan daripada rakan-rakan, komuniti dan masyarakat melalui komunikasi dan menggunakan bahasa tersebut dalam semua urusan harian (Klein, 1986). Tahap 
keyakinan pelajar yang ingin bertutur dalam bahasa Inggeris boleh jatuh merudum hanya melalui teguran negatif atau kritikan yang menjatuhkan oleh orang sekeliling.

Meskipun begitu, berdasarkan soalan 1, 13 dan 14, kebanyakan responden menjawab 'setuju' bahawa mereka kerap menggunakan kamus untuk merujuk kepada perkataan dalam bahasa Inggeris yang tidak difahami (47\%), tiada masalah mengendalikan sistem yang menggunakan bahasa Inggeris (58\%), tiada masalah untuk memahami bentuk-bentuk hiburan yang berasaskan bahasa Inggeris (62\%) dan berminat untuk mengikuti kursus untuk menambah-baik kemahiran berbahasa Inggeris (52\%). Ini menunjukkan bahawa responden boleh menerima bahasa Inggeris dan bersedia untuk meningkatkan kemahiran walaupun penguasaan mereka masih berada pada tahap sederhana.

Bersandarkan analasis ini didapati bahawa kelemahan utama bahasa Inggeris dalam kalangan pelajar tahun satu dalam kajian ini adalah dari segi kemahiran berkomunikasi dan kemahiran menulis. Responden mempunyai keyakinan yang rendah dan tidak mempraktikkan penggunaannya semasa bersosial dan berkomunikasi secara lisan terutama di khalayak ramai, tetapi tidak berhadapan dengan masalah untuk melakukan urusan seharian seperti mengendalikan peralatan yang menggunakan arahan dalam bahasa Inggeris, menikmati hiburan seperti filem, permainan dalam talian, menonton drama atau filem dan sebagainya. Walaupun mereka tidak begitu fasih berbahasa Inggeris, mereka akan merujuk kamus apabila berhadapan dengan perkataan yang tidak difahami, malah mereka bersikap positif untuk meningkatkan kemahiran berkenaan dengan bersedia mengikuti mengikuti kursus-kursus berkaitan sekiranya diberi peluang. Usaha penambahbaikan kemahiran berbahasa Inggeris boleh dilakukan kerana tahap penerimaan mereka yang positif memandangkan keperluan yang besar dalam dunia moden masa kini.

\section{Kesimpulan}

Berdasarkan dapatan kajian, dapat disimpulkan bahawa penguasaan bahasa Inggeris dalam kalangan pelajar tahun satu di UKM berada pada tahap sederhana. Bahasa Inggeris masih terhad penggunaannya walaupun semasa perbincangan dalam kumpulan kecil, atau di dalam dewan kuliah, malah, responden kurang berkeyakinan untuk bertanya kepada pensyarah menggunakan bahasa Inggeris. Selain itu, mereka juga belum menguasai sepenuhnya kemahiran menulis dalam bahasa Inggeris. Responden juga memerlukan persekitaran yang sesuai untuk mendorong penggunaan Bahasa Inggeris dalam kehidupan seharian. Responden juga mempunyai keyakinan yang tinggi untuk membuat rujukan dalam bahasa Inggeris kerana kefahaman mereka terhadap pembacaan berada pada tahap yang tinggi.

Bersandarkan analisis ini juga didapati bahawa kelemahan utama bahasa Inggeris responden adalah dari segi kemahiran berkomunikasi dan kemahiran menulis. Dapatan kajian juga dapat merumuskan persoalan kajian yang kedua, iaitu sama ada tahap penggunaan bahasa Inggeris mempengaruhi tahap penguasaan pelajar tahun satu di UKM terhadap bahasa ini. Mereka tidak berkeyakinan untuk mempraktikkan penggunaannya semasa bersosial dan berkomunikasi secara bertulis dan lisan terutama di khalayak ramai. Ini menunjukkan bahawa kekerapan 
penggunaan bahasa Inggeris terbukti mempengaruhi tahap penguasaan, sedangkan kebanyakan responden jarang menggunakan bahasa Inggeris dalam komunikasi seharian.

Walau bagaimanapun, responden didapati tidak berhadapan dengan masalah untuk melakukan urusan seharian seperti mengendalikan peralatan yang menggunakan arahan dalam bahasa Inggeris, menikmati hiburan seperti filem, permainan atas talian, menonton drama atau filem dan sebagainya. Walaupun mereka tidak begitu fasih berbahasa Inggeris, mereka akan merujuk kamus apabila berhadapan dengan perkataan yang tidak difahami, malah mereka bersikap positif untuk meningkatkan kemahiran berkenaan dengan bersedia mengikuti mengikuti kursus-kursus berkaitan sekiranya diberi peluang. Usaha penambahbaikan kemahiran berbahasa Inggeris boleh dilakukan kerana tahap penerimaan mereka yang positif memandangkan keperluan yang besar dalam dunia moden masa kini.

Walaupun dikatakan bahawa $70 \%$ daripada graduan Universiti Awam dan institusi pengajian tinggi berhadapan dengan masalah pengangguran, kajian Goi dan Lau (2010) mendapati hanya $4.8 \%$ sahaja melibatkan graduan lepasan UKM. Penekanan kepada kemahiran yang diperlukan oleh majikan adalah berbeza-beza bergantung kepada jenis pekerjaan dijalankan. Penguasaan Bahasa Inggeris yang lemah bukanlah faktor utama berlaku pengangguran dalam kalangan graduan UKM, namun begitu tahap pencapaian Bahasa Inggeris yang lemah turut menyumbang terhadap wujudnya situasi berkenaan. Graduan perlu dibekalkan dengan kemahiran tertentu untuk meningkatkan kebolehpasaran mereka seperti kerja berpasukan, komunikasi, penyelesaian masalah, keupayaan menyesuaikan diri dan kepimpinan. Semua ciri ini disuntik secara tak langsung ke dalam personaliti pelajar sepanjang pengalaman pembelajaran di universiti termasuk melalui latihan industri dan latihan di tempat kerja.

\section{Penghargaan}

Terima kasih kepada Nurshahirah Azman, Nur llyana Che Yusoff, Nursuhada Nordin, Siti Nor Fadilah Saleh, Nur Hazwani Ramlee dan Nur Hafizah Rasid yang membantu kajian ini.

\section{Rujukan}

Abu Bakar, Z., \& Abang Madni, D. R. (2010). Penggunaan Bahasa Inggeris di kalangan pelajar diploma kejuruteraan awam di fakulti kejuruteraan awam UITM, Sarawak. pp. 1-8. (Unpublished) http://eprints.utm.my/11331/

Abdul Halim, M. H., Hidzir, F. H., Woon, N. S., \& Marriappen, G. K. (2011). Kajian maklumbalas mengenai penggunaan Bahasa Inggeris sebagai bahasa pengantar dalam peperiksaan akhir di kalangan pelajar diploma akauntasi semester. Dalam Prosiding Seminar Majlis Dekan-dekan Pendidikan IPTA 2011, 335-351.

Abdul Latif, A., \& Abu Hanifah, A. (2010). Penguasaan dan penggunaan Bahasa Inggeris dalam kalangan pelajar-pelajar PKPG kemahiran hidup Universiti Teknologi Malaysia (m.s 1-13). (Unpublished) http://eprints.utm.my/10799/ 
Abdullah, N. M. R. (2007). Institusi pengajian tinggi penjana pembangunan modal insan kelas pertama. Dalam Prosiding Persidangan Pengajaran dan Pembelajaran di Peringkat Pengajian Tinggi 2007 (CTLHEO7), Selangor, Malaysia.

Abedi, J., Lord, C., \& Plummer, J. (1995). Language background as a variable in NAEP Mathematics performance. Los Angeles, Center for the Study of Evaluation, Standards and Student Testing.

Ary, D., Jacobs, L. C., \& Razaveih, A. (1990). Introduction to research in education (4th ed.). Orlando: Harcourt Brace Publishers.

Berita Harian. (2005, April 2). Siswazah disaran kuasai bahasa Inggeris dan komunikasi, m.s 4.

Bochner, S. (1996). The learning strategies of bilingual versus monolingual. The British Journal of Educational Psychology, 11, 279-295.

Carhill, A. (2008). Explaining English Language proficiency among adolescent immigrant students. American Educational Research Journal, 45(4), 11551179.

Goi, C. L., \& Lau, C. S. H. (2010). Graduates' employment: The value of Curtin University of Technology Sarawak's graduates. International Journal of Marketing Studies, 2(1), 127-132.

Haron, I., Gapor, A. L., Masran, M. I., Ibrahim, A. H., \& Mohamed Nor, M. (2008). Kesan dasar pengajaran Matematik dan Sains dalam Bahasa Inggeris di sekolah rendah. Dalam Laporan penyelidikan Fakulti Sains Kognitif Dan Pembangunan Manusia, Universiti Pendidikan Sultan Idris.

Ishak, T., \& Mohamed, M. (2012). Pengajaran dan pembelajaran Sains dan Matematik dalam Bahasa Inggeris (PPSMI): Suatu isu berulang. Jurnal Teknologi, 53(1), 95-106.

Ismail, M. H. (2012). Kajian mengenai kebolehpasaran siswazah di Malaysia: Tinjauan dari perspektif majikan. Prosiding Persidangan Kebangsaan Ekonomi Malaysia ke VII (PERKEM VII), 2, 906- 913.

Kamsur, N. (2015). Tahap penguasaan, sikap dan minat pelajar kolej kemahiran tinggi Mara terhadap mata pelajaran Bahasa Inggeris. Laporan projek Sarjana, Pendidikan Teknikal (Rekabentuk Instruksional dan Teknologi), Universiti Tun Hussein Onn Malaysia.

Kementerian Pengajian Tinggi Malaysia. (2010, Mac). Perangkaan Pengajian Tinggi Malaysia 2009. Putrajaya: Kementerian Pengajian Tinggi Malaysia.

Klein, W. (1986). Second language acquisition. Cambridge: Cambridge University Press.

Majlis Peperiksaan Malaysia. (2006). Malaysian University English Test: Regulations, Test Specifications, Test format and sample questions. http://www.mpm.edu.my/documents/10156/c5c332ab-3d97-495983c009866eea0774

Maniam, U. M., \& Liong, C. Y. (2007). Persepsi pelajar terhadap atribut pekerjaan dan implikasinya ke atas Pendidikan Universiti, dlm. Sains Malaysiana 36(2), 213-223. 
Mohamed, M., \& Mokhter, S. A. (2010). Persepsi pelajar UITM terhadap pengajaran dan pembelajaran Sains dan Matematik dalam Bahasa Inggeris. (Tidak diterbitkan) 1-10. Retreived from http://eprints.utm.my/11551/

Kamarudin, M. F., Sidek, M., Abdul Majid, I., Ibrahim, I., Mohamad Sharif, S., \& Mohamed, M. N. A. (2008, Ogos 18). Tahap penguasaan Bahasa Inggeris di kalangan staf akademik di sebuah Universiti Teknikal. Dalam Seminar Kebangsaan Kemahiran Insaniah dan Kesejahteraan Sosial (SKIKS), Hotel Mahkota, Melaka. Retreived from http://eprints.uthm.edu.my/2311/

Konting, M.M. (2000). Kaedah penyelidikan. Kuala lumpur: Dewan Bahasa dan pustaka.

Mohamed, M. (2008). Globalization and its impact on the medium of instruction in higher education in Malaysia. International Education Studies, 1(1), 90-94.

Nambiar, R., Noraini Ibrahim, \& Krish, P. (2008). Penggunaan strategi pembelajaran bahasa dalam kalangan pelajar Tingkatan Dua. Jurnal E-Bangi, 3(3), 1-17.

Selamat, A. R. (2000). Kemahiran dalam sekolah bestari. Johor Bharu, Malaysia: Badan Cemerlang Sdn. Bhd.

The Star. (2006a, Julai 4). 70\% jobless grads from public varsities, Retreived from http://www.thestar.com.my/news/nation/2006/07/04/70-jobless-gradsfrom-public-varsities/

The Star. (2006b, Ogos 6). A boon for jobless grads, m.s 2.

The Sun Daily. (2006, Ogos 6). $70 \%$ of grads from public institutions jobless, Retreived from http://www.thesundaily.my/node/173527

Yahaya, Hashim, \& Che Shariff. (2008). Pengajaran Sains Dan Matematik dalam Bahasa Inggeris. Dalam Yusof Boon \& Seth Sulaiman (Ed.), Permasalahan dalam pendidikan Sains Dan Matematik. Skudai: Penerbit Universiti Teknologi Malaysia.

Yahaya, M. F, Mohd Noor, M. A., Mokhtar, A. A., Mohd Rawian, R., Othman, \& Jusoff, K. (2009). Teaching of Science and Mathematics in English: The teachers' voices. English Language Teaching, 2(2), 141-147. DOI: http://dx.doi.org/10.5539/elt.v2n2p141 